\title{
Effects of transglutaminase enzyme on physicochemical properties of milkfish (Chanos chanos) surimi gel
}

\author{
Yuliana, I., "Mahendradatta, M. and Laga, A. \\ Department of Agricultural Technology, Faculty of Agriculture, Hasanuddin University, Makassar, \\ Indonesia.
}

\author{
Article history: \\ Received: 8 December 2020 \\ Received in revised form: 31 \\ January 2021 \\ Accepted: 21 April 2021 \\ Available Online: 7 \\ November 2021
}

Keywords:

Milkfish,

Gel,

Transglutaminase enzyme

DOI:

https://doi.org/10.26656/fr.2017.5(6).720

\begin{abstract}
Milkfish is one type of fish that can be used as raw material for surimi. However, previous research indicated that the quality of surimi powder produced from milkfish needed some improvements in order to produce surimi with good texture and strength gel. The addition of microbial transglutaminase (MTGase) enzyme is expected to produce surimi with better gel characteristics. The research objectives were to determine the best enzyme concentration and reaction time in the formation of surimi gel and to determine the effect of enzyme addition on the physical and chemical characteristics of surimi gel produced. The research was divided into two stages: 1) preparation for making surimi, and 2) determination of enzyme concentration and reaction time for surimi gel formation. The research treatment consisted of two factors, which were enzyme concentration $(0,0.1,0.3$, 0.5 units $/ g$ of surimi) and reaction time $(0,30,60$ mins $)$. The observation parameters consisted of yield, gel strength, whiteness, $\mathrm{pH}$, water content, protein content, and fat content. The results showed that the best concentration of MTGase enzyme was 0.5 units/ $\mathrm{g}$ with a reaction time of 60 mins. The addition of transglutaminase enzyme gave an effect significantly on gel strength, whiteness, protein content, and fat content in the milkfish surimi gel produced.
\end{abstract}

\section{Introduction}

Surimi is a myofibril protein obtained from fish meat that has been through the bone mechanically removed process and mixed by cryoprotectant materials. In general, surimi is processed through chopping, washing, mixing with cryoprotectants, and freezing (Nurkhoeriyati et al., 2010). In surimi making, the washing process is a critical stage. A large amount of water is used to remove sarcoplasmic proteins, blood, fat, and other nitrogen components that can affect surimi quality (Tanuja et al., 2014). Washing is known to increase the concentration of myofibril protein to increase the strength of the surimi gel (Hassan et al., 2017). In addition to the washing process, the addition of salt to surimi is also proven to increase the gel's strength in surimi (Tanuja et al., 2014).

Fish species often used as raw material for making surimi in Indonesia come from low-cost fish (Djazuli et al., 2009). One type of fish that can be used as raw material for making surimi is milkfish (Chanos chanos). Milkfish has a high nutritional value. According to the USDA National Nutrient Database For Standard
Reference (2013), milkfish contains $20.53 \%$ protein and $6.73 \%$ fat so that it is classified as high protein and medium fat fish (Junianto, 2003).

The surimi yield value of milkfish produced in the research of Sarie et al. (2018) was 58.72\%. The highest yield was obtained in milkfish surimi compared to tilapia, Belida fish, and jackfruit seed fish. So that milkfish is one type of fish that can be used as raw material for surimi. However, based on the research results of Malle et al. (2019), it was found that the quality of surimi powder from milkfish was still not good, because the value of the strength of the gel produced was still below the SNI Surimi standards. The milkfish surimi powder's strength value ranged from 407.41 to 574.26 g.cm, while the SNI strength surimi gel minimum of $600 \mathrm{~g} . \mathrm{cm}$.

An important quality attribute of surimi products is its elastic texture from the strength of surimi gel. To increase the strength of the surimi gel produced, it can be done by adding other additives that can form a gel so that it can improve the texture of the surimi. The additional material that can be given is the transglutaminase 
enzyme (Wang et al., 2018). One of the benefits of using the transglutaminase enzyme is to improve gel formation and gel properties (Grades, 2006).

The use of the transglutaminase enzyme has never been applied in the manufacture of surimi made from milkfish. So, in this study, researchers tried to make surimi using the transglutaminase enzyme and it is hoped that the addition of this enzyme can improve the quality of surimi both physically and chemically. The addition of the microbial transglutaminase (MTGase) enzyme is expected to produce better gel characteristics of surimi. MTGase has been widely used to improve protein-based products' texture, including surimi (Hemung and Chin, 2013). The mechanism of action of the transglutaminase enzyme is that the transglutaminase enzyme catalyzes the reaction between lysine amino acid residues and glutamine amino acid residues, and forms a lysine isopeptide $\varepsilon^{-}$- $\gamma$-glutamyl $)$ bond which results in the incorporation of inter or intramolecular covalent bonds that are cross-linked with food proteins (Nielsen et al., 1995). The essential amino acids make up $49.49 \%$ of the total amino acids in milkfish. Lysine is one of the essential amino acids in milkfish, $7.3 \%$, while glutamic acid is the dominant type of essential amino acid, which is $16.2 \%$ (Murthy et al., 2016).

The content of lysine and glutamic acid in milkfish meat is quite high, so it can increase the enzyme action in forming surimi gel. However, it is not known the concentration of enzyme addition and the length of action of the enzyme, which is effective for producing surimi gel with good chemical and physical characteristics. This study aimed to determine the best enzyme concentration and working duration to produce a good quality surimi gel made from milkfish.

\section{Materials and methods}

\subsection{Material}

The main ingredient in this research was fresh milkfish (Chanos chanos) obtained from the Makassar fish market. Other ingredients used include sucrose, a microbial transglutaminase enzyme produced by Shaanxi Fuheng Biotechnology Co. Ltd (Shaanxi, China), $\mathrm{NaCl}$, water, and ice.

\subsection{Preparation for surimi making}

The making of surimi began with separating the meat from the bone that it produced mashed meat. After that, the fish meat was grounded then washed and filtered using cold water at $10^{\circ} \mathrm{C}$ three times. The ratio of washing water and fish meat was 3: $1(\mathrm{v} / \mathrm{w})$. After, it was filtered and pressed. The fish meat was mixed with $4 \%$ sucrose, then packed and stored at $-18{ }^{\circ} \mathrm{C}$.

\subsection{Determination of enzyme concentrations and reaction time to form surimi gel}

The second stage was made of surimi gel. The frozen surimi from the stage was thawed until it reached $5^{\circ} \mathrm{C}$, then $2.5 \% \mathrm{NaCl}$ was added. Then, homogenization with ice was carried out until the surimi's water content was $80 \%$ and surimi paste was obtained. Furthermore, the addition of the MTGase enzyme (control, $0.1 \mathrm{unit} / \mathrm{g}, 0.3$ unit/g, 0.5 unit/g) was mixed at $5^{\circ} \mathrm{C}$ for 5 mins, then packed tightly in a plastic cylinder. Next was the enzymatic process, which was heated using a water bath at a temperature of $45^{\circ} \mathrm{C}$ based on the specified reaction duration (control, 30 mins, and 60 mins). Then proceeded with enzyme inactivation using a water bath at $90^{\circ} \mathrm{C}$ for 20 mins. After that, it was cooling at room temperature and stored for $24 \mathrm{hrs}$ at $4^{\circ} \mathrm{C}$.

\subsection{Surimi yield}

The surimi yield was calculated by comparing the surimi weight with the weight of whole fish meat. The whole fish meat was weighed as initial weight (a). Then the meat has been crushed, washed, squeezed, and then weighed as the final weight (c). Then the surimi results were calculated by the formula:

$$
\text { yield }(\%)=\frac{c}{a} \times 100
$$

The measurements were performed in triplicate for each surimi. The results were averaged.

\subsection{Gel strength}

The surimi gel's strength was analyzed using a texture analyzer (Type TA-XT2i Stable Micro Systems, Surrey, UK). Samples with a length of $2.5 \mathrm{~cm}$ were placed under a probe with a diameter of $Y$ inches with a measurement speed of $10 \mathrm{~mm} / \mathrm{s}$. Then the sample was pressed with the cylindrical probe. The gel strength value was obtained by multiplying the compressive strength $(\mathrm{g})$ of the tool with the resulting distance $(\mathrm{cm})$ until the surimi pieces were broken (Balange and Benjakul, 2009).

\subsection{Whiteness}

The colour analysis was performed with a Chromameter (type CR 200, Minolta Corp., Osaka, Japan). Analysis of the sample was carried out with three replications. The instrument was calibrated with a white marker card (CR-A43) until the monitor shows the values of $\mathrm{L}^{*}, \mathrm{a} *$, and $\mathrm{b} *$ according to the values listed in standard white, then the sample was placed in a tube with the lens covered and the reflectance value $\left(\mathrm{L}^{*}, \mathrm{a} *\right.$, and $\mathrm{b} *$ ) are read on a measuring device. The measurements were performed in triplicate for each sample. The results were averaged (Debusca et al., 
2013).

\section{$2.7 \mathrm{pH}$ analysis}

The sample was weighed as much as $1 \mathrm{~g}$, added 20 $\mathrm{mL}$ of water then shaken with a stirrer until completely homogeneous. After 15 mins the $\mathrm{pH}$ is measured. The measurements were performed in triplicate for each sample. The results were averaged.

\subsection{Water content}

The sample was weighing as much as $3 \mathrm{~g}$ was placed into a plate that has been dried and weighed. The sample was dried in an oven at $105^{\circ} \mathrm{C}$ for $6 \mathrm{hrs}$ then chilled in a desiccator for 15 mins and weighed. The drying and weighing process was carried out until it reaches a constant weight (AOAC, 2005). The measurements were performed in triplicate for each surimi. The results were averaged.

\subsection{Protein content}

Protein content analysis was performed using the Kjeldahl method. Approximately $2 \mathrm{~g}$ of sample and $1 \mathrm{~g}$ of selenium was put into the Kjeldahl tube and hydrolyzed with $20 \mathrm{~mL}$ of concentrated sulfuric acid $\left(\mathrm{H}_{2} \mathrm{SO}_{4}\right)$. The process of destruction was done in an hour. After cooling, the process was distilled, titrated, and cleaned to obtain the protein content. The measurements were performed in triplicate for each sample. The results were averaged.

\subsection{Fat content}

A total of $5 \mathrm{~g}$ of the sample was put into filter paper. Both ends of the wrap were covered with fat-free cotton and then put into the fat sleeve. The wrapped sample was put in a fixed weight fat flask and connected to the Soxhlet tube. The fat shell was put into the Soxhlet tube extractor chamber and doused with fat solvent (benzene), then refluxed for $6 \mathrm{hrs}$. The fat solvent in the fat flask was distilled off until all the fat solvent has evaporated. At the time of distillation, the solvent will be accommodated in the extractor room, then the fat flask was dried in an oven at a temperature of $105^{\circ} \mathrm{C}$, after which the flask was chilled in a desiccator until its weight was constant. The measurements were performed in triplicate for each sample. The results were averaged (AOAC, 1995).

\subsection{Data analysis}

Data The data were analysed by using a two-way Analysis of variance (ANOVA) with SPSS version 16.0. Duncan's multiple range tests were carried out to find out a significant difference between means of experimental data at a $5 \%$ level of significance.

\section{Results and discussion}

\subsection{Surimi yield}

Milkfish surimi yield is the amount of surimi that can be produced by the milkfish raw material used. The yield of meat and surimi milkfish at each washing can be seen in Figure 1. The yield value was measured starting from the weight of whole fresh milkfish to producing surimi. The yield of milkfish meat produced was $46.53 \%$. The yield value of milkfish surimi decreased with the increasing number of washings. In the first washing, the meat yield decreased by $6.76 \%$ to $39.78 \%$, for the second washing decreased by $0.36 \%$ to $39.42 \%$, and the third washing reduced the meat yield by $1.96 \%$ to $37.47 \%$ by weight of whole meat. Based on the yield value obtained from each processing stage, it showed that there was a decrease in the weight of the fresh fish material to become surimi, which was $62.53 \%$. The washing process can remove sarcoplasmic protein, blood, fat and other nitrogen components that can affect the quality of surimi (Tanuja et al., 2014).

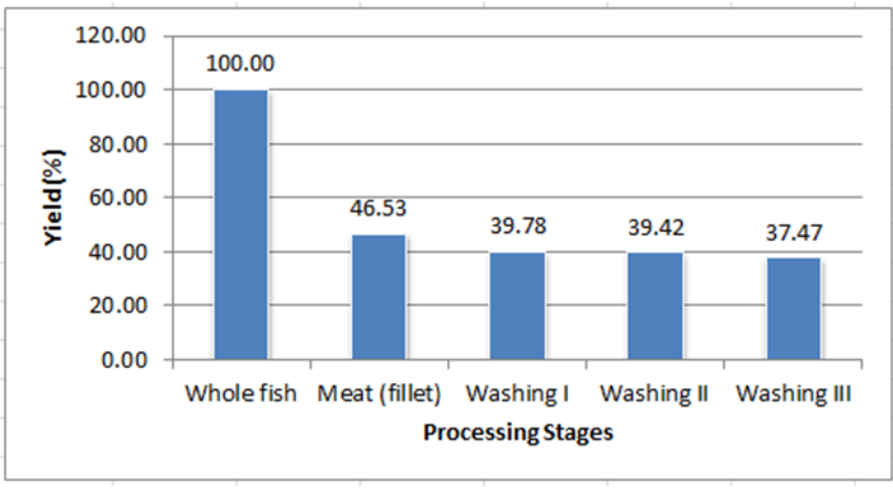

Figure 1. The yield of milkfish meat and surimi

\subsection{Gel strength}

Based on the test results, the concentration of the addition of enzyme and the length of the reaction to the strength of the milkfish surimi gel obtained values ranging from 1532.98 g.cm - 3242.05 g.cm. Analysis of variance showed that the enzyme concentration had a significant effect on the strength of the milkfish surimi gel $(p<0.05)$, but the reaction time and the interaction between the two had no significant effect.

The average value of surimi gel strength for milkfish in the control sample (without enzyme) was 1987.12 g.cm, the sample with an enzyme concentration of 0.1 unit/g was 2525.60 , at a concentration of 0.3 units/g of 2467.10 , and a concentration of $0.5 \mathrm{unit} / \mathrm{g}$ of 2765.81 g.cm. The results of the Duncan method's further test on the enzyme concentration showed that the control sample was significantly different from the sample with the addition of the transglutaminase enzyme at the enzyme concentration of 0.1 and 0.5 units/g, but it was not significantly different from the sample at the enzyme concentration of 0.3 units $/ g$. The results of the Duncan 
method's further test on the enzyme concentration are shown in Figure 2.

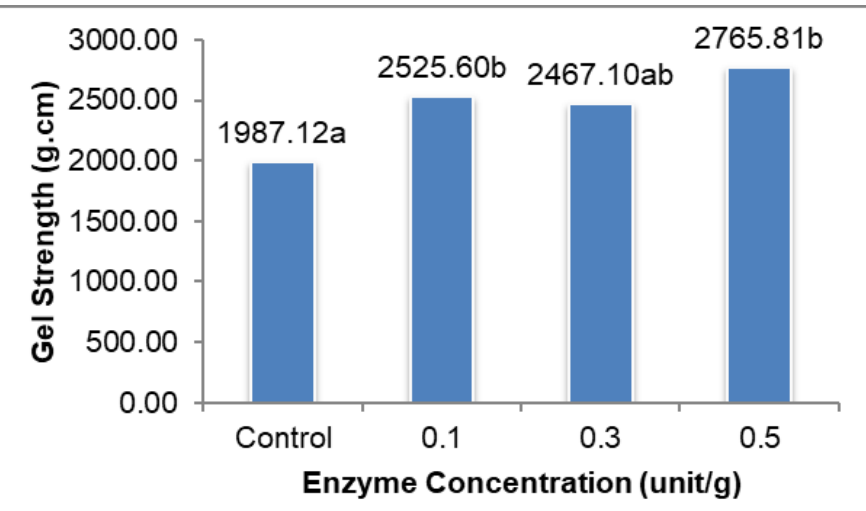

Figure 2. Relation of enzyme concentration to the strength of milkfish surimi gel. Different alphabet notations above the bars indicate significant difference $(\mathrm{p}<0.05)$.

Figure 2 shows that the gel strength value increased after the addition of the transglutaminase enzyme. Ramirez et al. (2006) stated that the addition of TGase to mashed meat can increase the strength of the gel. Chanarat and Benjakul (2013) state that, the formation of non-disulfide covalent bonds in proteins, in particular the lysine $\varepsilon^{-}$( $\gamma$-glutamyl $)$ cross-link, is catalyzed by MTGase through acyl transfer between the $\gamma$-amide groups of the glutamine residue and the $\varepsilon$-amino groups of a lysine residue, contributing to the improvement of gel quality in surimi.

\subsection{Whiteness}

Based on the test results, the concentration of the addition of enzyme and the duration of the reaction to the whiteness of the milkfish surimi gel obtained values ranging from 76.12 to 79.54 . The results of an analysis of variance showed that the enzyme concentration and reaction time had a significant effect on the whiteness of the milkfish surimi gel $(p<0.05)$, however the interaction between the two had no significant effect $(\mathrm{p}>0.05)$.

The average value of the white degree of surimi gel for milkfish in the control sample (without enzyme) was 79.19 , the sample with an enzyme concentration of 0.1 unit/g was 78.84 , at a concentration of 0.3 units/g of 77.88 , and a concentration of 0.5 units/g valued at 77.30 . The results of the Duncan method's further test on the enzyme concentration showed that the degree of whiteness obtained in the control sample (without enzyme) was significantly different from the sample with the addition of the transglutaminase enzyme at an enzyme concentration of 0.3 and 0.5 units/g, but not significantly different from the sample at the concentration. enzyme $0.1 \mathrm{unit} / \mathrm{g}$. As for samples with an enzyme concentration of 0.3 units $/ g$, it was not significantly different from samples with an enzyme concentration of 0.5 units $/ \mathrm{g}$. The profile of the change in whiteness based on the enzyme concentration is shown in Figure 3.

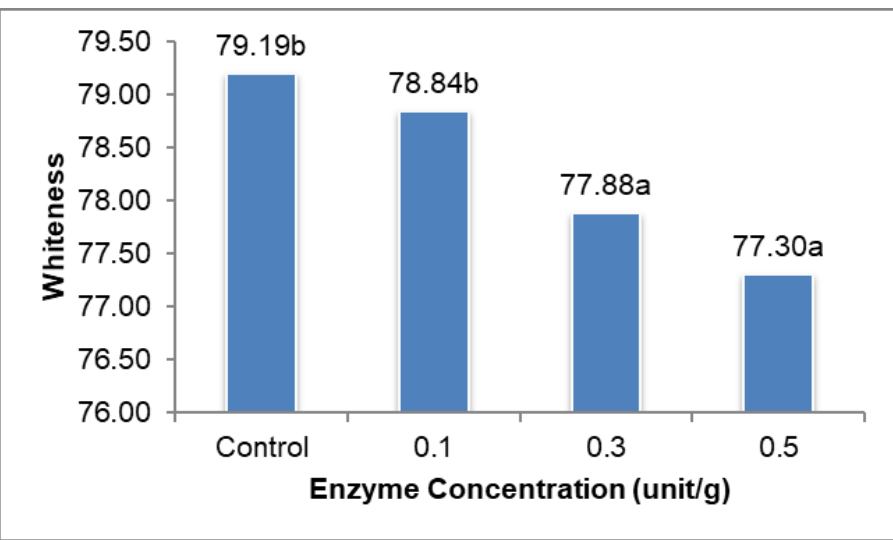

Figure 3. Relation of enzyme concentration to the whiteness of milkfish surimi gel. Different alphabet notations above the bars indicate significant difference $(\mathrm{p}<0.05)$

Decreasing in the whiteness value after the addition of the enzyme was caused by a combination of the colour of the raw material with the colour of the enzyme added. Lanier et al. (1985) stated that the whiteness value of the surimi can be influenced by the type of fish, the washing process, and the colour particles of the ingredients added. The addition of MTGase enzyme in a certain concentration did not significantly affect the whiteness value of milkfish surimi gel.

The average value of the white degree of surimi gel for milkfish in the control sample (without enzyme reaction) was 79.26 , the sample with a reaction time of 30 mins was 78.28 , and the sample with a reaction time of 60 mins was 77.37. The results of Duncan's continued test of the reaction time showed that the degree of whiteness obtained was significantly different for each treatment. The profile of the change in the degree of white based on the reaction time was shown in Figure 4.

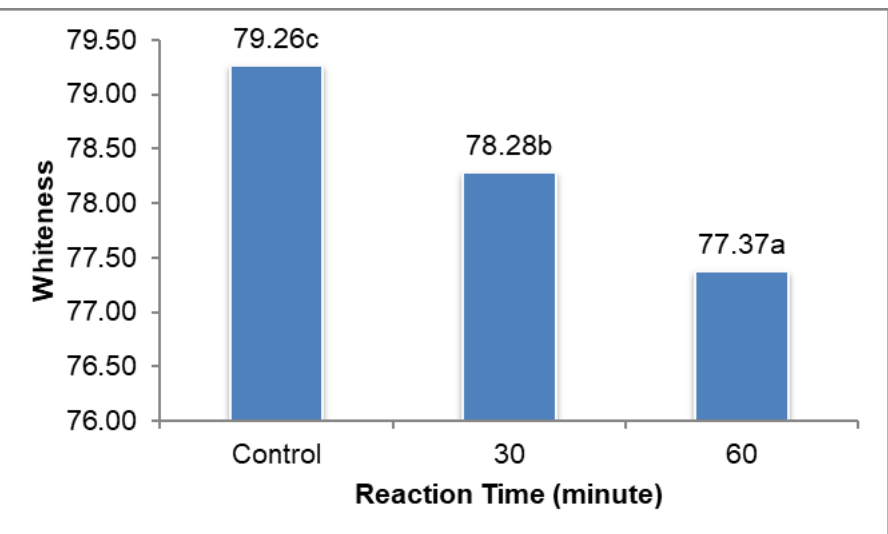

Figure 4. Relation of reaction time to the whiteness of milkfish surimi gel. Different alphabet notations above the bars indicate significant difference $(p<0.05)$.

Figure 4 shows the degree of whiteness of the milkfish surimi gel in the control treatment (without reaction) decreased after it had heated at $45^{\circ} \mathrm{C}$. Treatment without enzymatic reaction (without heating at $45^{\circ} \mathrm{C}$ ) had a higher whiteness value than treatment 
with heating at $45^{\circ} \mathrm{C}$. However, in general, the colour seen visually for all samples was white.

\subsection{Acidity level ( $p H)$}

Changes in $\mathrm{pH}$ value affected the properties of connective tissue in meat. The $\mathrm{pH}$ value caused denaturation of myofibril protein, then adversely affect the formation of surimi gel (Suvanich et al., 2000). Based on the test results, the $\mathrm{pH}$ value of milkfish surimi gel obtained based on the enzyme concentration and reaction time for all treatments ranged from 6.29 to 6.50 . The $\mathrm{pH}$ value is classified as a stable $\mathrm{pH}$. Suzuki (1981) stated that actomyosin is relatively more stable in the $\mathrm{pH}$ range of 6-8. The results of the analysis of variance showed that the reaction time treatment had a significant effect on the $\mathrm{pH}$ value of the surimi gel $(\mathrm{p}<0.05)$, but the enzyme concentration and the interaction between the two treatments did not affect the $\mathrm{pH}$ value of the surimi gel $(p>0.05)$ significantly.

The average $\mathrm{pH}$ value of milkfish surimi gel in the control sample (without enzyme reaction) was 6.49 , the sample with a reaction time of 30 mins obtained a value of 6.32 , and the sample with a reaction time of 60 mins was 6.33. The results of Duncan's continued test on the reaction time showed that the $\mathrm{pH}$ value obtained in the control sample (without enzyme reaction) was significantly different from the sample with a reaction time of 30 and 60 mins, while the surimi gel with a reaction time of 30 and 60 mins resulted in a $\mathrm{pH}$ value that was not significantly different. The profile of changes in $\mathrm{pH}$ values based on enzyme concentration is shown in Figure 5.

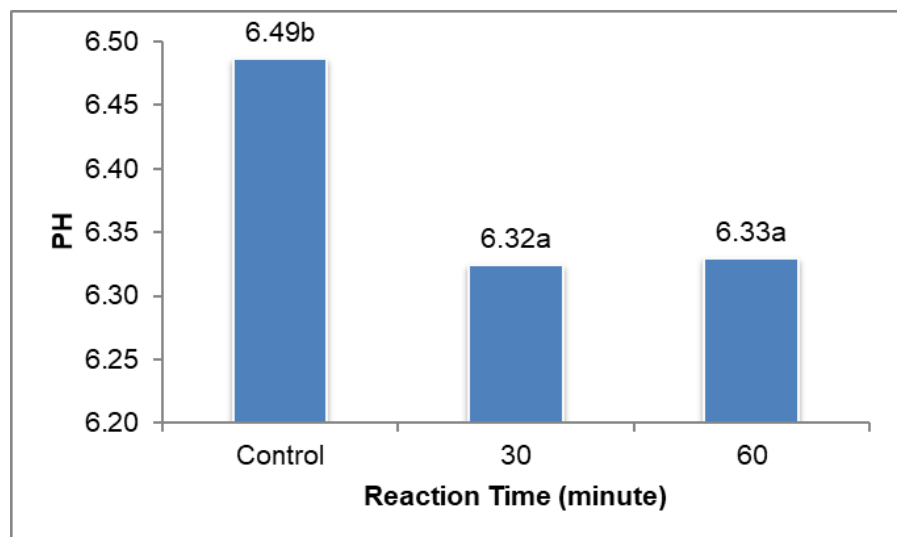

Figure 5. Relation of reaction time to the $\mathrm{pH}$ value of milkfish surimi gel. Different alphabet notations above the bars indicate significant difference $(\mathrm{p}<0.05)$.

The addition of the MTGase enzyme in various concentrations had no significant effect on the $\mathrm{pH}$ value of the milkfish surimi gel because the addition of the transglutaminase enzyme in the manufacture of surimi gel was not a factor that affected changes in $\mathrm{pH}$ values, both decreasing and increasing the $\mathrm{pH}$ value. This is in line with the statement of Ando et al. (1989), that
MTGase does not change the $\mathrm{pH}$, colour and taste of food.

\subsection{Water content}

The test results of the addition of enzyme concentration and reaction time to the water content of milkfish surimi gel obtained values ranging from 75.67$76.89 \%$. The analysis of variance showed that the reaction time and interaction between the two treatments had a significant effect on the water content of milkfish surimi gel, but the enzyme concentration treatment had no significant effect $(\mathrm{p}>0.05)$. The profile of changes in water content based on the interaction of enzyme concentration and reaction time is shown in Figure 6.

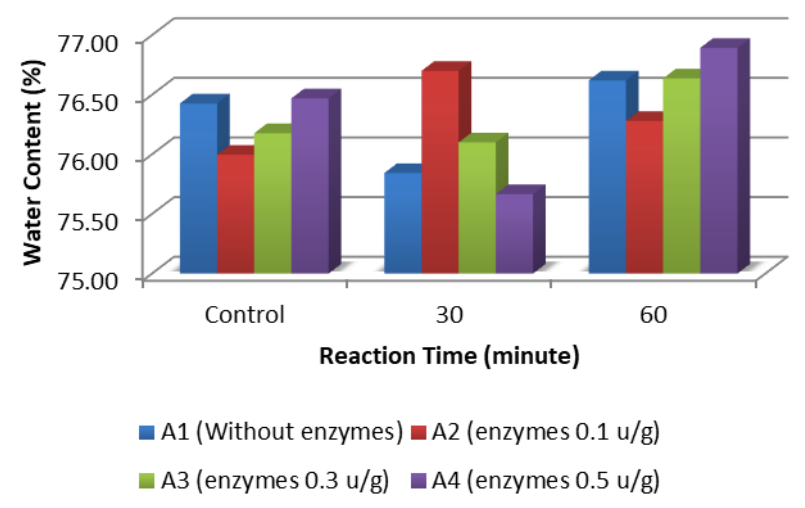

Figure 6. The interaction and relationship between enzyme concentration and reaction time to water content of milkfish surimi gel.

The average water content of milkfish surimi gel in the control sample (without enzyme reaction) was $76.27 \%$, the sample with a reaction time of 30 mins was $76.08 \%$, and the sample with a reaction time of 60 mins was $76.61 \%$. The results of Duncan's continued test on reaction time showed that the control sample (without enzyme reaction) was significantly different from the 60 minute reaction time, but not significantly different from the 30-min reaction time. The reaction time related to water content in surimi gel can be seen in Figure 7.

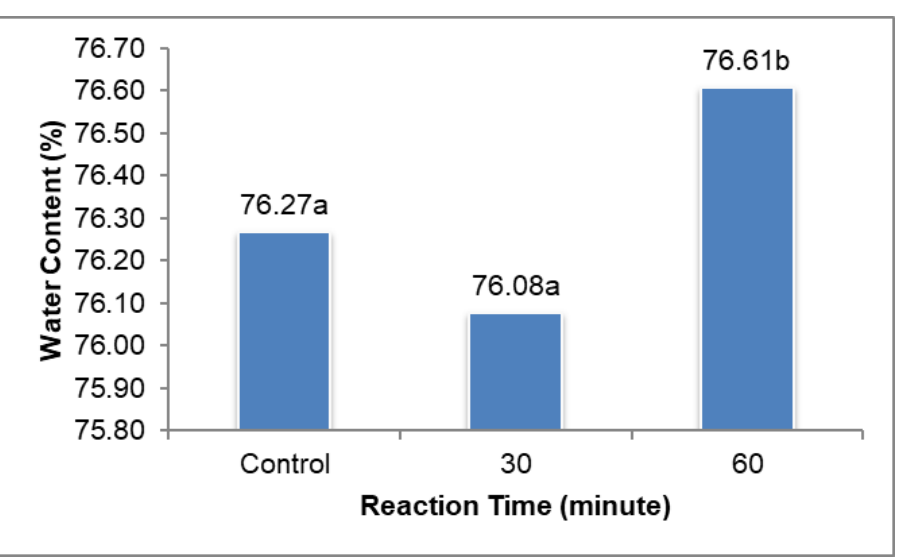

Figure 7. Relation of reaction time to the water content of milkfish surimi gel. Different alphabet notations above the bars indicate significant difference $(\mathrm{p}<0.05)$. 
The water content in the sample with a reaction time of 30 mins was lower than that of the sample with 60 mins reaction time. It was because the heating time resulted in the gelatinization process. The gelatinization process occurs because water enters the cells so that the starch granules can swell and affect the water content in a material (Cahya et al., 2019).

The enzyme concentration did not significantly affect the water content of milkfish surimi gel. The addition of MTGase increased protein cross-linking to some degree, resulting in a stronger tissue with a greater water-binding capacity (Chanarat and Benjakul, 2013). The water content of each treatment produced in the study met the SNI (Indonesian National of Standard). Surimi water content requirement based on SNI 2694: 2013 is a maximum of $80 \%$. The water content of the surimi gel produced was in the range of $75.67-76.89 \%$, the water content value was quite high. The increasing water content in surimi gel is caused by the loss of water -soluble components such as blood, pigments, proteins, mineral salts during processing, thereby increasing the hydration process of the fish meat (Suvanich et al., 2000). The increase in water content also contributes to myofibril proteins' activity such as actin and myosin that bind immobilized water (Haard et al., 1994). This is related to the statement by Suvanich et al. (2000) during the washing process, myofibril protein hydration occurs, where the water component diffuses into the myofibril protein matrix.

\subsection{Protein content}

The test results of the addition of enzyme concentration and reaction time to the protein content of milkfish surimi gel obtained values ranging from 3.61$19.20 \%$. The lowest protein content was obtained in the addition of the enzyme with a concentration of $0.1 \mathrm{unit} / \mathrm{g}$ with a reaction time of 30 mins, namely $3.61 \%$. The highest protein content was obtained in the treatment of the enzyme concentration of 0.5 units/g with a reaction time of 60 mins, namely $19.20 \%$. The results of the analysis of variance showed that the enzyme concentration, reaction time, and the interaction between the two significantly affected milkfish surimi gel protein content. The profile of changes in protein content based on the interaction of enzyme concentration and reaction time is shown in Figure 8.

The average protein content of milkfish gel in control samples (without enzymes) was $16.26 \%$, for samples with an enzyme concentration of 0.1 unit/g of $11.08 \%$, at an enzyme concentration of 0.3 units/g of 16 , $11 \%$, and a concentration of 0.5 units/g of $18.02 \%$. The results of Duncan's continued test on the enzyme concentration showed that the protein levels obtained were significantly different for each treatment. The profile of changes in protein levels based on enzyme concentration is shown in Figure 8.

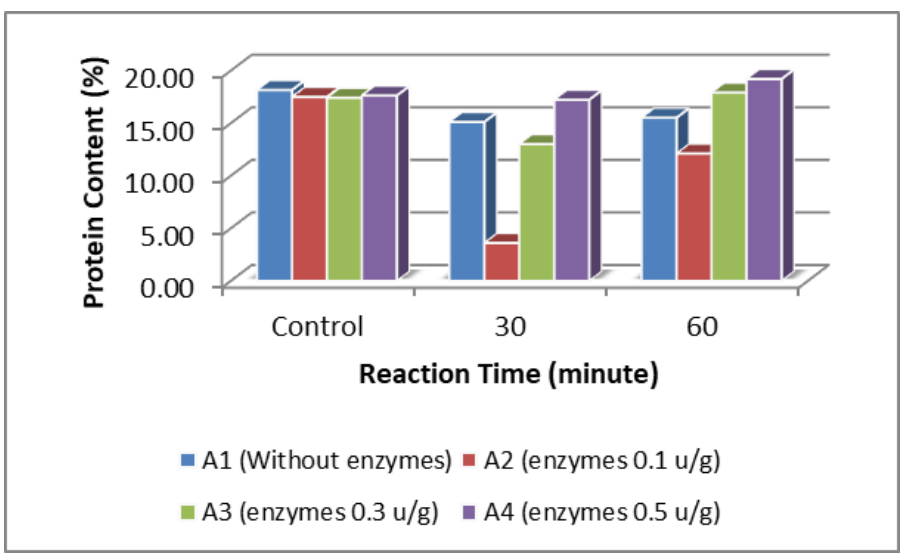

Figure 8. The interaction and relationship between enzyme concentration and reaction time on the protein content of milkfish surimi gel.

The MTGase enzyme concentration of 0.5 unit/g in milkfish surimi was chosen as the best treatment based on the protein content (Figure 9). The high content of lysine, glutamine, and enzymes increasing the protein content of milkfish surimi gel. This is related to Simbolon (2019) research, the higher concentration of lysine and glutamine, and the enzymes added, showed the higher protein content value of cross-linked rice flour. According to Gauche et al. (2008), MTGase catalyzes cross-linking and increases the molecular weight of proteins, thereby increasing the protein solution's viscosity.

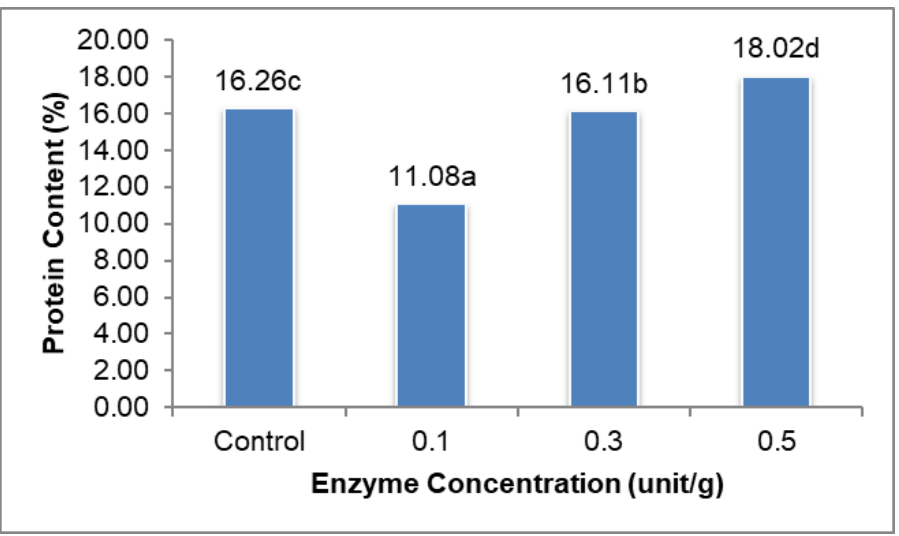

Figure 9. Relation of enzyme concentration to protein content of milkfish surimi gel.

The average protein content of milkfish surimi gel in the control sample (without enzyme reaction) was $17.68 \%$, the sample with a reaction time of 30 mins was $12.24 \%$, and the sample with a reaction time of $60 \mathrm{mins}$ was $16.19 \%$. The results of Duncan's further test on reaction time showed that the sample treatment (without enzyme reaction) was significantly different from each other treatment. The profile of changes in protein content based on reaction time is shown in Figure 10.

According to Susanti and Fibriana (2017), enzyme activity is influenced by several factors, one of which is 
substrate availability. Other factors that can cause crosslinking that have not run well are the inadequate process conditions, including crosstie time, stirring speed, and the type of stirrer used (Simbolon, 2019). Based on this, it was suspected that the cross-linking was not formed on some of the proteins with high concentration due to the less-than-optimal reaction time.

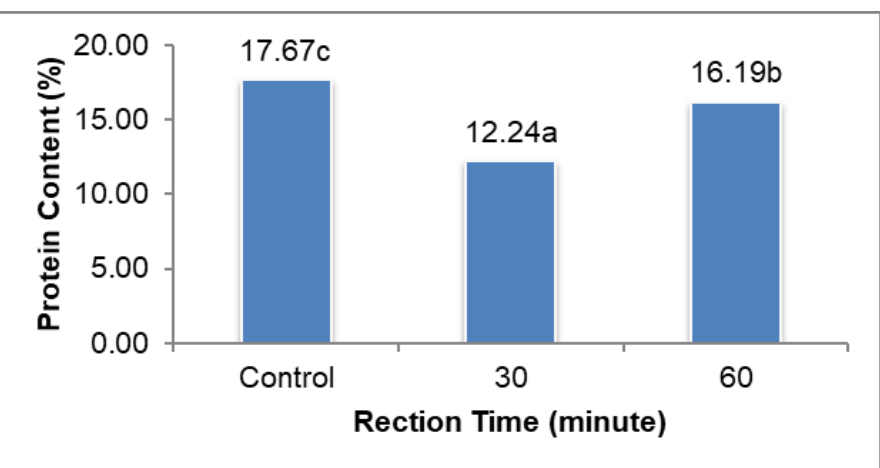

Figure 10. Relation of reaction time to the protein content of milkfish surimi gel. Different alphabet notations above the bars indicate significant difference $(\mathrm{p}<0.05)$.

\section{7 Fat content}

Fat content is an important concern in the process of making surimi because it affects the quality of the surimi gel produced. The presence of fat can interfere with the gel formation process (Wijayanti, 2012).

The results of testing the different enzyme concentrations and reaction times on the fat content of the milkfish surimi gel were found to be between 3.25$14.54 \%$. The lowest fat content was found in the treatment of the enzyme concentration of 0.5 units $/ g$ without an enzymatic reaction of $3.25 \%$. The highest fat content was found in the treatment without the addition of enzymes with a reaction time of 30 mins, amounting to $14.54 \%$. The results of the analysis of variance showed that the enzyme concentration, reaction time, and the interaction between the two significantly affected the fat content of milkfish surimi gel. The profile of changes in fat content based on the interaction of enzyme concentration and reaction time is shown in Figure 11.

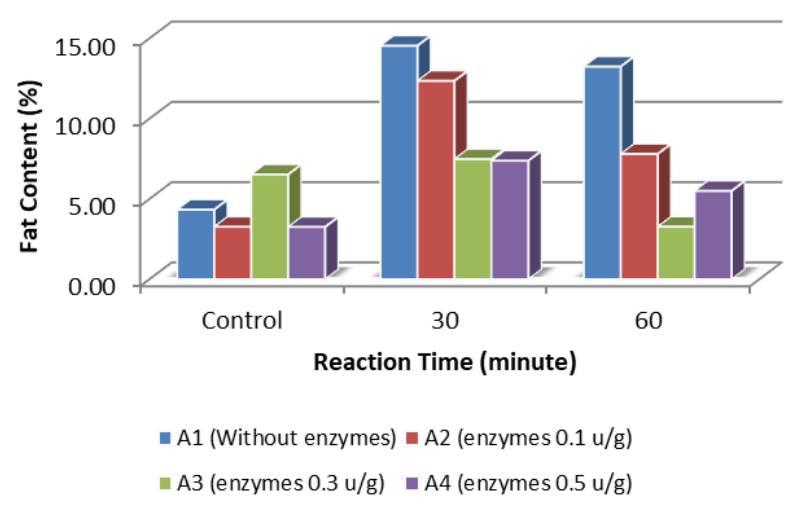

Figure 11. The interaction and relationship between enzyme concentration and reaction time on the fat content of milkfish surimi gel.

eISSN: $2550-2166$
The average fat content of milkfish surimi gel in the control sample (without enzyme) was $10.70 \%$, the sample with an enzyme concentration of $0.1 \mathrm{unit} / \mathrm{g}$ was $7.80 \%$, at a concentration of $0.3 \mathrm{unit} / \mathrm{g}$ of $5.76 \%$, and at a concentration of $0.5 \mathrm{unit} / \mathrm{g}$ of $5.38 \%$. The results of Duncan's further test on the enzyme concentration showed that the control sample (without enzyme) was significantly different from each other treatment. The relationship between enzyme concentration and fat content in surimi gel is shown in Figure 12.

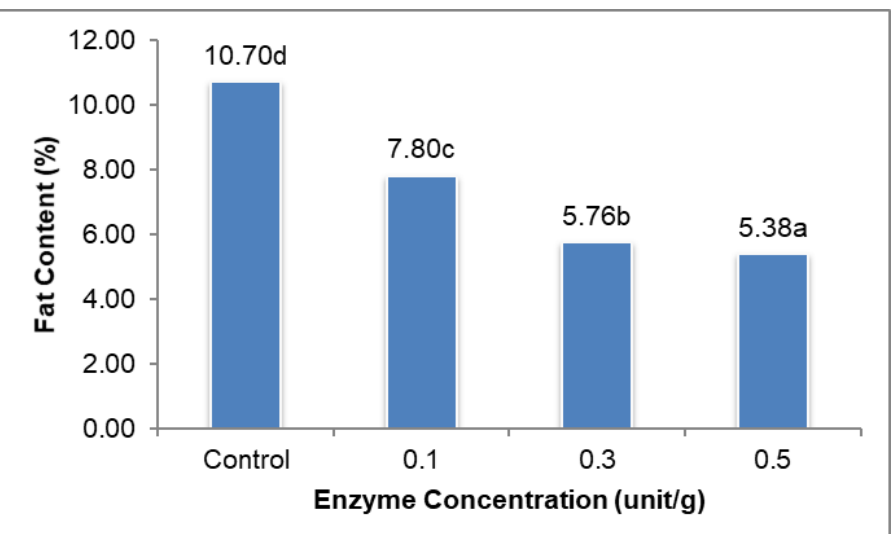

Figure 12. Relation of enzyme concentration to fat content of milkfish surimi gel. Different alphabet notations above the bars indicate significant difference $(\mathrm{p}<0.05)$.

The results showed a decrease in the fat content of milkfish surimi gel after the addition of the MTGase enzyme and an increase in fat levels after heating for 30 and 60 mins. The addition of the transglutaminase enzyme, in addition, was increasing the strength of the gel and reducing the fat content in the resulting surimi gel. The gel strength has an inverse correlation with fat content because fat is a barrier factor for gelling if the fat content is low, the value of gel strength is high (Anggraeni et al., 2017).

The average fat content of milkfish surimi gel in the control sample (without enzyme reaction) was $4.34 \%$, the sample with a reaction time of 30 mins was $10.44 \%$, and the sample with a reaction time of 60 mins was $7.45 \%$. The results of Duncan's continued test of the

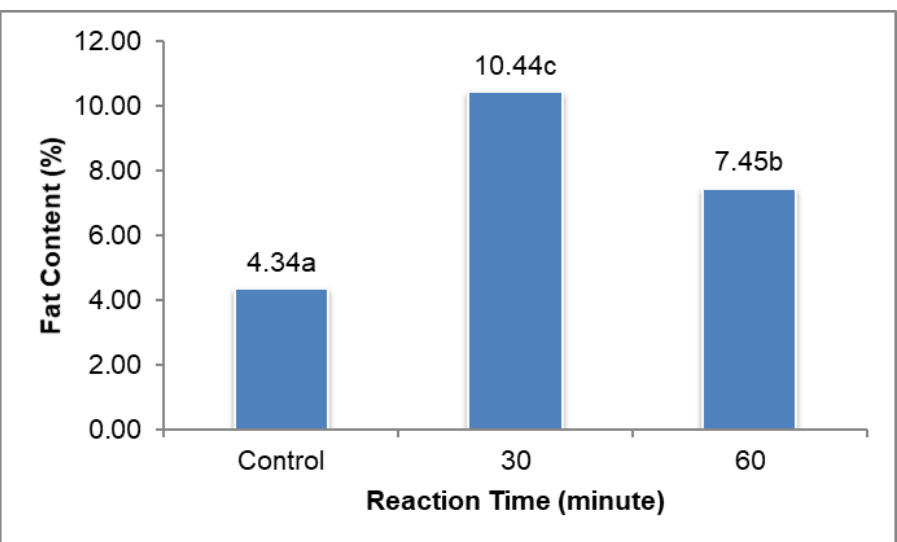

Figure 13. Relation of reaction time to the fat content of milkfish surimi gel. Different alphabet notations above the bars indicate significant difference $(\mathrm{p}<0.05)$.

(C) 2021 The Authors. Published by Rynnye Lyan Resources 
reaction time showed that the control sample (without enzyme reaction) was significantly different from the sample at the reaction time of 30 and 60 mins, as well as the sample reaction time of 30 mins which was significantly different from the reaction time of 60 mins. The reaction time related to the fat content in the surimi gel is shown in Figure 13.

\section{Conclusion}

The best concentration of MTGase addition was 0.5 units/g of surimi with reaction time of $60 \mathrm{mins}$ had gel strength of $3242.05 \mathrm{~g} . \mathrm{cm}$, protein content of $19.20 \%$, and fat content of $5.50 \%$. The addition of transglutaminase enzyme gave an effect significantly on gel strength, whiteness, protein content, and fat content in the milkfish surimi gel produced.

\section{Conflict of interest}

The authors declare no conflict of interest.

\section{Acknowledgments}

The author would like to thank to Kemenristek Dikti for funding this research through a Magister theses research grant for the year 2020 .

\section{References}

Ando, H., Adachi, M., Umeda, K., Matsuura, A., Nonaka, M., Uchio, R., Tanaka, H. and Motoki, M. (1989). Purification and Characteristics of a novel transglutaminase derived from microorganisms. Agricultural and Biological Chemistry, 53(10), 2613 -2617. https://doi.org/10.1271/bbb1961.53.2613

Anggraeni, R., Vanessa, N.J.L., Indah, K. and Supriyadi. (2017). Karakteristik surimi ikan cucut. Agrikan Jurnal Agribisnis Perikanan, 10(2), 36-43. https:// doi.org/10.29239/j.agrikan.10.2.36-43 [In Bahasa Indonesia].

AOAC. (1995). Association of Official Analytical Chemists: Official Method of Analysis. Washington, USA: AOAC Inc.

AOAC. (2005). Association of Official Analytical Chemists: Official Method of Analysis. Washington, USA: AOAC Inc.

Balange, A.K. and Benjakul, S. (2009). Enhancement of gel strength of big-eye snapper (Priacanthus tayenus) surimi using oxidised phenolic compounds. Journal Food Chemistry, 113(1), 61-70. https:// doi.org/10.1016/j.foodchem.2008.07.039

Cahya, S.U., Zuprizal, Chusnul, H. dan Wihandoyo. (2019). Pengaruh lama pemanasan terhadap kualitas kimia wheat pollard yang berpotensi sebagai prebiotik. Jurnal Aplikasi Teknologi Pangan, 8(3). https://doi.org/10.17728/jatp.5262 [In Bahasa Indonesia].

Chanarat, S. and Benjakul, S. (2013). Impact of microbial transglutaminase on gelling properties of Indian mackerel fish protein isolates. Food Chemistry, 136(2), 929-937. https://doi.org/10.1016/ j.foodchem.2012.09.021

Debusca, A., Tahergorabi, R., Beamer, S.K., Partington, S. and Jaczynski, J. (2013). Interactions of dietary fibre and omega-3-rich oil with protein in surimi gels developed with salt substitute. Food Chemistry, 141 (1), 201-208. https://doi.org/10.1016/ j.foodchem.2013.02.111

Djazuli, N., Wahyuni, M., Monintja, D. and Purbayanto, A. (2009). Modifikasi teknologi pengolahan surimi dalam pemanfaatan "By-Catch" pukat udang di Laut Arafura. Jurnal Pengolahan Hasil Perikanan Indonesia, 12(1), 17-30. [In Bahasa Indonesia].

Gauche, C., Joana, T.C.V., Paulo, J., Ogliari, M.T. and Bordignon-Luiz. (2008). Crosslinking of milk whey proteins by transglutaminase. Process Biochemistry, 43(7), 788-794. https://doi.org/10.1016/ j.procbio.2008.04.004

Grades, Z.E.A. (2006). Stability of microbial transglutaminase and its reactions with individual caseins under atmospheric and high pressure. Germany: Fakultät Mathematik und Naturwissenschaften, Technischen Universität Dresden.

Haard, N.F., Simpson, B.K. and Pan, B.S. (1994). Sarcoplasinic proteins and other nitrogenous compounds. New York, USA: Chapman and Hall. https://doi.org/10.1007/978-1-4615-7828-4_3

Hassan, M.A., Balange, A.K., Senapati, S.R. and Xavier, K.A. (2017). Effect of different washing cycles on the quality of Pangasius hypophthalmus surimi. Fishery Technology, 54, 51-59.

Hemung, B. and Chin, K. (2013). Effects of fish sarcoplasmic proteins on the properties of myofibrillar protein gels mediated by microbial transglutaminase. Food Science and Technology (Campinas), 53(1), 184-190. https://doi.org/10.1016/ j.lwt.2013.02.008

Junianto. (2003). Teknik Penanganan Ikan. Jakarta, Indonesia: Penebar Swadaya.

Lanier, T.C., Donald, D.H. and Wu, M.C. (1985). Application of functional measurements to least cost linear programming of surimi based product formulations. Proceedings of the International Symposium on Engineered Seafood Including Surimi., p. 264-273. Seattle, Washington. 
Malle, S., Abu, B.T., Mulyati, M.T. and Maryati, B., (2019). Physicochemical properties of milkfish (Chanos chanos) surimi powder. International Journal of Scientific Research in Science and Technology, 6(1), 14-21. https://doi.org/10.32628/ IJSRST19614

Murthy, L.N., Padiyar, P.A., Rao, M. and Asha, K.K. (2016). Nutritional profile and heavy metal content of cultured milkfish (Chanos chanos). Fishery Technology, 53(2016), 245 - 249.

Nielsen, G.S., Peterson, B.R. and Moller, A.J. (1995). Impact of salt, phosphate and temperature on the effect of a transglutaminase on the texture of restructured meat. Meat Science, 41(3), 293-299. https://doi.org/10.1016/0309-1740(94)00002-O

Nurkhoeriyati, T., Huda, N. and Ahmad, R. (2010). Surimi-like material: challenges and prospects. International Food Research Journal, 17(3), 509517.

Ramirez, J., Uresti, R., Téllez, S. and Vázquez, M. (2006). Using salt and microbial transglutaminase as binding agents in restructured fish products resembling hams. Journal Food Science, 67(5), 1778 -1784 . https://doi.org/10.1111/j.13652621.2002.tb08722.x

Sarie, O.T., Asikin, A.N. and Kusumaningrum, I. (2018). Pengaruh perbedaan jenis ikan terhadap karakteristik gel surimi. Ziraa'ah, 43(3), 266-272.

Simbolon, E.P. (2019). Perbaikan karakteristik tepung beras dengan ikat silang lisin dan glutamin oleh enzim transglutaminase. Bogor, Indonesia: Bogor Agricultural University. [In Bahasa Indonesia].

Susanti, R. and Febriana, F. (2017). Teknologi Enzim. Yogyakarta, Indonesia: ANDI OFFSET. [In Bahasa Indonesia].

Suvanich, V., Jahncke, M.L. and Marshal, 1.D.L. (2000). Changes in selected chemical quality characteristics of channel catfish frame mince during chill and frozen storage. Journal Food Science, 65(1), 24-29. https://doi.org/10.1111/j.1365-2621.2000.tb15950.x

Suzuki, T. (1981). Fish and Krill Protein: Processing Technology. Netherlands: Springer. https:// doi.org/10.1007/978-94-011-6743-7

Tanuja, S., Viji, P., Zynudheen, A.A., Ninan, G. and Joshy, C.G. (2014). Composition, textural quality and gel strength of surimi prepared from striped catfish (Pangasianodon hypophthalmus Souvage, 1878). Fishery Technology, 51, 1-6.

Wang, L., Zhang, M., Bhandari, B. and Yang, C. (2018). Investigation on fish surimi gel as promising food material for 3D printing. Journal of Food Engineering, 220, 101-108. https://doi.org/10.1016/ j.jfoodeng.2017.02.029

Wijayanti, I. (2012). Pengaruh penambahan komponen fenolik teroksidasi terhadap karakteristik gel surimi ikan lele dumbo. Bogor, Indonesia: IPB, Bsc. Thesis. [In Bahasa Indonesia]. 